Journal of Animal and Veterinary Advances 9 (9): 1295-1300, 2010

ISSN: $1680-5593$

(C) Medwell Journals, 2010

\title{
DRB3 Gene Polymorphism and Somatic Cell Count in Milk of Jersey Cows
}

\author{
Katarzyna Wojdak-Maksymiec, M. Kmiec, Inga Kowalewska-Luczak and M. Warliñski \\ Department of Animal Genetics and Breeding, Agricultural University of Szczecin, \\ ul. Doktora Judyma 6, 72-466 Szczecin, Poland
}

\begin{abstract}
The aim of this study was to investigate associations between BoLA-DRB3 polymorphism and Somatic Cell Count (SCC) in milk, daily milk yield and milk fat and protein percentage content. DNA used in the study was obtained from 184 Jersey cows from Wielkopolska region in Poland. The frequencies of DRB3/HaeIII alleles and genotypes were determined. Four alleles of the following frequencies were found: A-0.560; B- 0.195 ; D-0.008 and E-0.236. The association between DRB3/HaeIII polymorphism and SCC (transformed into a logarithmic scale) was analysed with regard to parity, season, stage of lactation, year of study and cow as sources of variability. Statistically significant associations were found with regard to all the analysed factors. The highest SCC was recorded in milk of EE-genotype cows, whereas the lowest SCC was found in BB-genotype cows. The study also included the effect of DRB3/HaeIII genotype on daily milk yield and fat and protein content in milk. DRB3/HaeIII genotype was found to be non-significant for these traits. The results obtained in this study suggest that BoLA-DRB3 is a candidate marker for SCC and consequently for mastitis resistance/susceptibility in dairy cows.
\end{abstract}

Key words: DRB3 polymorphism, somatic cell count, milk utility traits, jersey cow, dairy cow, poland

\section{INTRODUCTION}

Mastitis (udder infection) poses a major problem in the management of dairy cows. Producers suffer huge losses due to veterinary treatment costs or in some cases, necessary culling of infected animals. Milk of cows afflicted with mastitis is not suitable for consumption, which also leads to a reduction in the profitability of the production process.

The occurrence of mastitis is influenced by both environmental and genetic factors as well as interactions between them (Lindhe and Philipsson, 1998). Susceptibility to mastitis is also associated with the anatomical structure of the udder (including the structure of the teats), cow hygiene and milking technology (Smith and Hogan, 1993; Faye et al., 1994; Elbers et al., 1998; Barkema et al., 1999; Whitaker et al., 2000; Waller et al., 2003; Koster et al., 2006a, b).

Mastitis prevention in dairy cows by improving environmental conditions has proved to be ineffective. Despite the considerable advances in cow-keeping technologies, the incidence of udder infection remains high in particular in high-production herds (Oltenacu and Ekesbo, 1994). Therefore, more effective methods of preventing this disease have to be found. One of them is to base cow breeding on the differences in hereditary susceptibility to mastitis. The differences are observed among breeds as well as individual animals. Thus, it seems reasonable to use Marker Assisted Selection (MAS).

Several studies have been conducted with the aim of locating genes that affect resistance to mastitis in cattle. Immune response to this disease is induced and regulated by among other factors, Major Histocompatibility Complex (MHC) gene products.

In cattle, MHC (BoLA) genes (which are located on chromosome 23) have been extensively evaluated as candidate markers for associations with various bovine diseases and immunological traits (Andersson and Davies, 1994; Lewin, 1996; Lewin et al., 1999). Such associations have been reported by many researchers (Glass et al., 1991; Xu et al., 1993; Dietz et al., 1997a, b; Sharif et al., 1998; Maillard et al., 2003).

Specifically, associations between both class I and II genes and the incidence of mastitis have been found (Oddgeirsson et al., 1988; Lunden et al., 1990; Schukken et al., 1994; Sharif et al., 1998).

Moreover, bovine $\mathrm{MHC}$ also appears to influence other than immunological traits, namely milk yield growth and reproduction. Sharif et al. (1999), Machado et al. (2005) and Vukasinovic et al. (1997) found statistically significant associations between DRB3 alleles and milk utility traits. In cattle, the MHC gene is the most widely studied class II gene as it is extremely polymorphic with

Corresponding Author: Katarzyna Wojdak-Maksymiec, Department of Genetics and Animal Breeding, Agricultural University of Szczecin, ul. Dr Judyma 6, 72-466 Szczecin, Poland 
over 90 different alleles detected (Takeshima et al., 2001). In recent years, the studies on DRB3 polymorphism have benefited from the development of PCR-RFLP methods (Van Eijk et al., 1992; Gelhaus et al., 1995). DRB3 polymorphism is recognized by three restriction enzymes (RsaI, BstYI and HaeIII) and is characterized by a large number of gene variants.

The aim of this study was to search for associations between DRB3 gene polymorphism and susceptibility/ resistance to mastitis and milk production traits in a population of Jersey cows. The primary trait used to evaluate susceptibility to mastitis is Somatic Cell Count (SCC). SCC enables indirect selection for resistance to mastitis. A number of factors justify the use of SCC:

- SCC is relatively easy and inexpensive to collect

- Estimates of genetic correlations between SCC and clinical mastitis are sufficiently high

- The heritability of SCC is 2-3 times greater than the heritability of clinical mastitis

- SCC is an indicator of not only clinical but also subclinical infections

\section{MATERIALS AND METHODS}

The study included a herd of 184 dairy Jersey cows from Wielkopolska region in Poland. All the animals were kept in identical environmental conditions. They were fed standard feed ratios and seasonally (in spring and summer) were put out to pasture. The cows were milked twice a day with the use of a pipeline milking machine. The herd's milk yield was evaluated with the A4 method in compliance with the recommendations of the International Committee for Animal Recording (ICAR). The data concerning SCC in milk, fat and protein content and daily milk yield were collected in the years 1998-2002 on the basis of monthly milking tests, representatively sampled (2513 samples) from both of two milkings performed at the same day time for each cow. SCC and fat and protein content in the samples were determined with an instrumental method in accordance with the PN-EN ISO/IEC 17025 standard, using Combifoss equipment (including Fossmatic 5000 and MilkoScan 6000 apparatuses, Foss, Hillerod, Denmark). The analyses were carried out in the ICAR and COFRAC certified laboratory of milk analyses in Krotoszyn, Poland. Percentage fat content was determined per weight ratio. Protein and fat content was expressed in g $100 \mathrm{~mL}(\%)$ and somatic cells in pcs $\mathrm{mL}^{-1}$. Calibration was completed on the basis of standardized test samples from the Central Laboratory of the National Animal Breeding Centre in Parzniew, Poland (ICAR and COFRAG certificates, CECALAIT member).
The Gerber and Röse-Gottlieb method was used as a reference method for determining fat content and the Kjeldahl method was used for determining protein content.

Analytical method: Peripheral blood was collected into tubes coated with an anti-coagulant and afterwards DNA was isolated. The isolation of DNA from the whole blood was done with a Master Pure ${ }^{\mathrm{TM}}$ DNA Purification Kit for Blood (Epicentre, USA).

The isolated DNA was used for a two-stage PCR amplification of the DRB3 gene fragment of $284 \mathrm{bp}$ (base pair) with the use of the following primers proposed by Van Eijk et al. (1992).

\section{First stage primers:}

Forward: 5'-ATCCTCTCTCTGCAGCACATTTCC-3'

Contains 7 nucleotides of the 5' and $3^{\prime}$ ends of exon 2 plus intron sequences.

Reverse: 5'-TTTAAATTCGCGCTCACCTCGCCGCT-3' Contains 8 nucleotides of the $5^{\prime}$ and $3^{\prime}$ ends of exon 2 plus intron sequences.

\section{Second stage primers:}

Forward: 5' - the same as in the first stage

Reverse: 5'-TCGCCGCTGCACAGTGAAACTCTC-3'

Consists entirely of nucleotides of the $3^{\prime}$ end of exon 2 and has an 8 basepair overlap with $3^{\prime}$ end of first stage reverse primer.

The PCR reaction was carried out in Biometra termocyclers (Whatman Biometra GmbH, Gottingen, Germany) according to Van Eijk et al. (1992) using Fermentas reagents (Fermentas, Madison, USA) and Proligo primers (Proligo France SAS). Restriction analysis of the amplified fragment was performed with the RFLP method using HaeIII enzyme (for $3 \mathrm{~h}$ with 5 units $/ 20 \mathrm{uL}$, at $35^{\circ} \mathrm{C}$ ). The restriction fragments were separated on high-resolution $4 \%$ agarose gels (MetaPhor ${ }^{\circledR}$, Cambrex Bioscience, Rockland, Inc., USA) containing ethidium bromide. Then, the fragments were visualized under UV light and their length was determined using a gel imaging and documentation system (Vilber Lourmat Deutschland GmbH, Eberhardzell, Germany).

Statistical methods: The frequencies of DRB3/HaeIII alleles and genotypes were determined and it was verified with $\chi^{2}$-test whether their observed distributions corresponded to the expected ones (according to the Hardy-Weinberg law). The statistical analysis also included a search for associations between DRB3/HaeIII polymorphism and SCC in milk. Only genotypes found in at least 10 individuals were included in the analysis. Parity, season, stage of lactation, year of study and cow 
(random factor nested in DRB3/HaeIII genotype as genetic background) were also considered as sources of variability. The year of animal's birth was not considered as a factor as it corresponded to the lactation number in the subsequent years of the study. Year was divided into four seasons: winter-from December-February, spring from March-May, summer-from June-August and autumn from September-November. Lactation stage was set as: stage I, from the 1st-4th month; stage II, from the 5-8th month and stage III, the 9th and subsequent months. Lactation number 5 and the subsequent ones were treated as one category, mainly due to the decreasing number of available cows of older age and the observed tendency of increasing SCC in milk in later lactations. SCC in milk was transformed into a logarithmic scale to obtain normal distribution of this trait.

The results of the analyses were processed statistically according to STATISTICA data analysis software system, version 7.0 with multiple-factor mixed nested model. Means and standard deviations for different levels of the studied factors were also calculated. The significance of differences between the means was verified with the Duncan test.

The effect of DRB3/HaeIII genotypes on daily milk yield and fat and protein content in milk in the year 2002 was also analysed. The influence of cow, season, parity and stage of lactation was considered. The model used here was analogous to the one described for the analysis of the effect of DRB3/HaeIII on SCC in milk.

\section{RESULTS AND DISCUSSION}

In the studied herd of dairy cows, four DRB3/HaeIII alleles-A, B, D and E were observed. The RFLs obtained by cutting the $284 \mathrm{bp} \mathrm{PCR}$ product were as follows: A-167, 65,52 ; B-219, 65; D- 190, 65, 29 and E-112, 87, 85. Their frequencies were as follows: A- $0.560 ; \mathrm{B}-0.195 ; \mathrm{D}-0.008$ and E-0.236. The alleles controlled the occurrence of eight out of ten possible genotypes. The results are shown in Table 1.
The RFLP of DRB3 gene was studied by Van Eijk et al. (1992). They identified 6 alleles cut with HaeII restrictase into the following fragments: a-167, 65, 52 ; b- 219, 65; c-167, 65, 49; d-190, 65, 29; e-167, 117 and $\mathrm{f}-167,65,48,4$ bp. The subsequent alleles: g-164, 65, 55; $\mathrm{h}-167,65,46,6$ and I-167, 113, 4 were identified by Gelhaus et al. (1995).

The frequencies of DRB3/HaeIII alleles were studied by Miretti et al. (2001). In this locus, they identified four alleles: $A, B, D$ and $E$ which determined ten possible genotypes: $\mathrm{AA}, \mathrm{BB}, \mathrm{DD}, \mathrm{EE}, \mathrm{AB}, \mathrm{AD}, \mathrm{AE}, \mathrm{BD}$ and $\mathrm{DE}$. The frequencies of the identified alleles were as follows: A-0.496; B-0.293; D-0.014 and E-0.224. Thus, these results are similar to those obtained in this study.

The fact that no alleles C, F, G, H and I were found in the studied population may result from their generally law frequency reported by other researchers in various breeds of cows. For example, Gilliespie et al. (1999) had found no alleles C, F, G, H and I in Jersey cows and similarly Miretti et al. (2001) had found no such alleles in seven populations of South American cattle.

Statistically significant difference was found in the studied population between the observed DRB3/HaeIII genotype distribution and the expected one estimated according to the Hardy-Weinberg law. The number of observed $\mathrm{BB}$ and $\mathrm{AE}$ genotypes was higher than that expected. On the other hand, there were fewer $\mathrm{EE}, \mathrm{AB}$ and $\mathrm{BE}$ genotypes compared with their expected numbers.

In this study, associations between $\ln$ SCC and DRB3/HaeIII genotype, parity, season, lactation stage, year of study and cow (nested in DRB3/HaeIII genotype) were investigated. The study included only genotypes with a frequency $>1 \%$. Statistically significant associations were found between $\ln$ SCC and all the studied factors. The results are shown in Table 2.

Mean values for $\ln \mathrm{SCC}$, their standard deviations as well as the significance of differences between the mean values are shown in Table 3 . The highest $\ln$ SCC

Table 1: Frequencies and distribution of DRB3 genotypes in the analysed herd

\begin{tabular}{|c|c|c|c|c|c|c|}
\hline $\begin{array}{l}\text { DRB3 } \\
\text { genotype }\end{array}$ & $\begin{array}{l}\text { Observed no. } \\
\text { of cows }\end{array}$ & $\begin{array}{c}\text { Observed } \\
\text { frequency }(\%)\end{array}$ & $\begin{array}{c}\text { Expected no. } \\
\text { of cows }\end{array}$ & $\begin{array}{c}\text { Expected } \\
\text { frequency }(\%)\end{array}$ & Obs.-exp. & $(\text { Obs.-exp. })^{\Upsilon}$ \\
\hline $\mathrm{AA}$ & 60 & 32.9670 & 57.1648 & 31.410 & 2.8352 & 0.1406 \\
\hline $\mathrm{BB}$ & 20 & 10.9890 & 6.9244 & 3.800 & 13.0756 & 24.6908 \\
\hline $\mathrm{DD}$ & 1 & 0.5495 & 0.0125 & 0.010 & 0.9877 & 78.9091 \\
\hline $\mathrm{EE}$ & 7 & 3.8462 & 10.1593 & 5.580 & -3.1593 & 0.9825 \\
\hline $\mathrm{AB}$ & 21 & 11.5385 & 39.7912 & 21.860 & -18.7910 & 8.8740 \\
\hline $\mathrm{AD}$ & 1 & 0.5495 & 1.6813 & 0.920 & -0.6813 & 0.2761 \\
\hline $\mathrm{AE}$ & 62 & 34.0659 & 48.1978 & 26.480 & 13.8022 & 3.9525 \\
\hline $\mathrm{BD}$ & 0 & 0.0000 & 0.5852 & 0.320 & -0.5852 & 0.5852 \\
\hline $\mathrm{BE}$ & 10 & 5.4945 & 16.7747 & 9.220 & -6.7747 & 2.7361 \\
\hline $\mathrm{DE}$ & 0 & 0.0000 & 0.7088 & 0.390 & -0.7088 & 0.7088 \\
\hline Total & 182 & 100.0000 & 182.0000 & 100.000 & 0.0000 & 121.8556 \\
\hline
\end{tabular}

$\chi^{2}=121.8556, \mathrm{df}=9, \mathrm{p}<0.000000$ 
Table 2: Associations between $\ln \mathrm{SCC}$ and the analy sed factors

\begin{tabular}{lccc}
\hline Sources of variability & Degree of freedom & F-statistics & Probability \\
\hline DRB3 genotype & 4 & 4.01804 & 0.002982 \\
Parity & 4 & 7.33075 & 0.000013 \\
Season & 3 & 9.12568 & 0.000018 \\
Stage of lactation & 2 & 15.04959 & 0.000000 \\
Year of study & 3 & 5.30452 & 0.001308 \\
Cow (nested factor & & & \\
in DRB3 genotype) & 173 & 5.39167 & 0.000000 \\
\hline
\end{tabular}

Table 3: Means and standard deviations of $\ln \mathrm{SCC}$ in milk related to the DRB3 genotype

\begin{tabular}{lcccc}
\hline Factors & No. & $\begin{array}{c}\text { Mean of } \\
\text { In SCC }\end{array}$ & $\begin{array}{c}\text { Standard } \\
\text { deviation }\end{array}$ & $\begin{array}{c}\text { Significance of } \\
\text { differences } \mathrm{p} \leq 0.01\end{array}$ \\
\hline DRB3 AA & 750 & 5.213 & 1.167 & 2,5 \\
DRB3 BB & 278 & 4.865 & 0.921 & $1,3,4$ \\
DRB3 AB & 297 & 5.162 & 1.083 & 2,5 \\
DRB3 AE & 899 & 5.303 & 1.168 & 2,5 \\
DRB3 BE & 147 & 4.928 & 1.155 & $1,3,4$ \\
Total & 2371 & 5.182 & 1.141 & \\
\hline
\end{tabular}

(transformed into a logarithmic scale) was recorded in milk of AE-genotype cows (5.303), whereas the lowest ln SCC was observed in BB-genotype cows (4.867).

The results obtained in this study confirmed the proposition that BoLA-DRB3 can be used as a marker of somatic cell concentration in milk and, in consequence, as a marker of susceptibility/resistance to mastitis in dairy cows. It was proved that there are associations between the allelic variants of the bovine MHC (BoLA) genes and the occurrence of disease and immune responsiveness in cattle (Xu et al., 1993; Schukken et al., 1994; Mallard et al., 1995; Sharif et al., 1998). For instance, Xu et al. (1993) found statistically significant associations between allelic variants of the class II BoLA-DRB3 gene and resistance or susceptibility to persistent lymphocyotsis caused by the Bovine Leukemia Virus (BLV).

The effect of DRB3 polymorphism on SCC in milk has been studied by many authors. Significant associations between SCC and various DRB3 haplotypes and alleles were established by Oddgeirsson et al. (1988), Mejdell et al. (1994), Schukken et al. (1994) and others. Sharif et al. (1998) studied DRB3 polymorphism in 835 Holstein cows and 66 Jersey cows. They found no associations between DRB3 alleles and Somatic Cell Score (SCS) in milk of Jersey cows. However, they established significant associations between DRB3.2*16 alleles and low SCS in Holstein cows. The fact that no such association was found in Jersey cows might have resulted from the small number of cows in the herd and consequently a low infection incidence rate. Associations between DRB3.2 ${ }^{*} 16$ allele and decreased SCC were also proved by Aarestrup et al. (1995) and Ashwell et al. (1996). Dietz et al. (1997a) on the other hand found that DRB3.2*16 allele had a significant effect on higher SCC in milk whereas Kelm et al. (1997) associated allele *23 with decreased SCC. A different result was obtained by Sharif et al. (1998), who found significant associations between allele ${ }^{*} 23$ and increased SCC.

DRB3 polymorphism recognized by three restriction enzymes (RsaI, BstYI and HaeIII) is characterized by a large number of gene variants. This corresponds to the actual variability within DRB3 gene but makes it difficult to indicate the correct marker. This great variability is likely to be the reason for contradictory results of studies on associations between various DRB3 alleles and resistance to udder infections. For example, Dietz et al. (1997a) and Kelm et al. (1997) associated allele *16 with a higher SCC, whereas Starkenburg et al. (1997) and Sharif et al. (1998) with a lower SCC. Moreover, Kelm et al. (1997) and Sharif et al. (2000) reported more cases of Clinical Mastitis (CM) in cows with allele ${ }^{*} 8$, whilst Starkenburg et al. (1997) reported fewer cases of CM is such cows. What is more, great differences in DRB3 allele frequencies are even found within one particular breed. For instance, in Jersey cows, allele *7 was found to be most frequent by Sharif et al. (1998) but was not found at all by Gilliespie et al. (1999). Therefore, it seems reasonable to study a single polymorphism recognized by only one restriction enzyme. DRB3 gene variants identified in this way do not fully reflect the variability of this locus but they meet the criteria of a good marker.

Table 4 shows associations between daily milk yield and fat and protein content and the analyzed factors, namely DRB3/HaeIII genotype, parity, season, lactation stage and cow. No statistically significant association was found between the studied traits and DRB3/HaeIII genotype.

Furthermore, no statistically significant association was found between the studied milk production traits and DRB3/HaeIII genotype in this study. Associations between DRB3 polymorphism and milk utility traits have also been studied by many researchers. Sharif et al. (1999) evaluated possible relationships between BoLA-DRB3 alleles and production traits, namely 305 days lactation milk yield and fat and protein yield in a population of Canadian dairy cows (Holstein, $n=835$ and Jersey, $n=66$ ) over the course of two lactations. No significant associations were found between BoLA alleles and the above-mentioned production traits in Jerseys. In Holsteins, no associations were found between alleles * 16 and $* 23$ and the production traits but allele $* 8$ was significantly associated with increased 305 day lactation milk, fat and protein yields. Allele * 22 on the other hand was associated with a lower milk and protein yield. Machado et al. (2005) studied associations between BoLA-DRB3.2 alleles identified by PCR-RFLP and milk production in Gir breed. Two BoLA-DRB3 alleles (*16 and *29) were found to be significantly associated with milk production, suggesting that BoLA-DRB3.2 locus itself or 
Table 4: Associations between daily milk yield fat and protein content and the analysed factors

\begin{tabular}{|c|c|c|c|c|c|c|}
\hline Factors & $\begin{array}{c}\text { Daily milk y ield } \\
\text { probability }\end{array}$ & Significance & $\begin{array}{l}\text { Fat content } \\
\text { probability }\end{array}$ & Significance & $\begin{array}{l}\text { Protein content } \\
\text { probability }\end{array}$ & Significance \\
\hline DRB3 genotype & 0.069745 & NS & 0.796472 & NS & 0.389171 & NS \\
\hline Parity & 0.000000 & $* * * *$ & 0.066358 & NS & 0.016039 & $*$ \\
\hline Season & 0.000000 & ******; & 0.000000 & 粎** & 0.000000 & ****** \\
\hline Stage of lactation & 0.000000 & ***** & 0.000000 & *w*** & 0.000000 & ***:*: \\
\hline $\begin{array}{l}\text { Cow (nested in } \\
\text { DRB3 genotype) }\end{array}$ & 0.000000 & *w* & 0.000000 & 㥆氺 & 0.000000 & 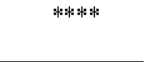 \\
\hline
\end{tabular}

a linked QTL influences milk yield in 305-day lactation of Gir cows. Associations between BoLA-DRB3 locus and economically important traits in Holstein cows were studied by Vukasinovic et al. (1997). Statistically significant association was found between BoLA-DRB3 locus and PTA for milk, fat and protein yield and fat percentage, which indicates that either DRB3 locus itself or a linked QTL influences these traits.

\section{CONCLUSION}

The results obtained in this study confirm the hypothesis of using DRB3 as a marker for SCC and what follows for resistance/susceptibility to mastitis in dairy cows. However, further studies are necessary to confirm these results before DRB3 is be used as a SCC marker in mass selection of dairy cattle.

\section{ACKNOWLEDGEMENT}

This study supported by the Agricultural University of Szczecin (Project BW/HB/09/2004).

\section{REFERENCES}

Aarestrup, F.M., N.E. Jensen and H. Ostergard, 1995. Analysis of associations between major histocompatibility comlex (BoLA) class I haplotypes and subclinical mastitis of dairy cows. J. Dairy Sci., 78: 1684-1692.

Andersson, L. and C.J. Davies, 1994. The Major Histocompatibility Complex. In: Cell-Mediated Immunity in Ruminants, Goddeeris, B.M. and W.I. Morrison (Eds.). CRC Press, London, pp: 37-62.

Ashwell, M.S., C.E. Rexroad, R.H. Miller and P.M. van Raden, 1996. Mapping economic triat loci for somatic cell score in holstein cattle using microsatellite markers and selective genotyping. Anim. Genet., 27: 235-242.

Barkema, H.W., Y.H. Schukken, T.J. Lam, M.L. Beiboer, G. Benedictus and A. Brand, 1999. Management practices associated with the incidence rate of clinical mastitis. J. Dairy Sci., 82: 1643-1654.
Dietz, A., J. Detilleux, A. Freeman, D. Kelly, J. Stabe and M. Jr. Kehrli, 1997a. Genetic associations of bovine lymphocyte antigen DRB3 alleles with immunological traits of Holstein cattle. J. Dairy Sci., 80: 400-405.

Dietz, A.B., N.D. Cohen, L. Timms and M.E. Jr. Kehril, 1997b. Bovine lymphocyte antigen class II alleles as risk factors for high somatic cell counts in milk of lactating dairy cows. J. Dairy Sci., 40: 406-412.

Elbers, A.R.W., J.D.P. Miltenburg, H.W. Barkema and Y.H. Shukken, 1998. Risk factors for clinical mastitis in a random sample of dairy herds from the southern part of the Netherlands. J. Dairy Sci., 81: 420-426.

Faye, B., N. Dorr, F. Lescourret, J. Barnouin and M. Chassagne, 1994. Farming practices associated with the udder infection complex. Vet. Res., 25: 213-218.

Gelhaus, A., L. Schnittger, D. Mehlitz, R.D. Horstmann and C.G. Meyer, 1995. Sequence and PCR-RFLP analysis of 14 novel BoLA-DRB3 alleles. Anim. Genet., 26: 147-153.

Gilliespie, B.E., B.M. Jayarao, H.H. Dowlen and S.P. Oliver, 1999. Analysis and frequency of bovine lymphocyte antigen DRB3.2 alleles in Jeresy cows. J. Dairy Sci., 82: 2049-2053.

Glass, E., R. Oliver, T. Collen, T. Doel, R. Dimarchi and R. Spooner, 1991. MHC class II restricted recognition of FMDV peptides by bovine $\mathrm{T}$ cells. Immunology, 74: 594-599.

Kelm, S.C., J.C. Deitilleux, A.E. Freeman, M.E. Jr. Kehrli and A.B. Dietz et al., 1997. Genetic association between parameters of innate immunity and measures of mastitis in preparturient Holstein cattle. J. Dairy Sci., 80: 1767-1775.

Koster, G., B.A. Tenhagen and W. Heuwieser, 2006a. Factors associated with high milk test day somatic cell counts in large dairy herds in Brandenburg. 1: Housing conditions. J. Vet. Med. A Physiol. Pathol. Clin. Med., 53: 134-139.

Koster, G., B.A. Tenhagen, N. Scheibe and W. Heuwieser, $2006 \mathrm{~b}$. Factors associated with high milk test day somatic cell counts in large dairy herds in Brandenburg. II. Milking practices. J. Vet. Med. Physiol. Pathol. Clin. Med., 53: 209-214. 
Lewin, H.A., 1996. Genetic Organization, Polymorphism and Function of the Bovine Major Histocompatability Complex. In: The Major Histocompatability Complex Region of Domestic Animals, Schook, L.B. and S.J. Lamont (Eds.). CRC Press, London, pp: 65-98.

Lewin, H.A., G.C. Russell and E.J. Glass, 1999. Comparative organization and function of the major histocompatibility complex of domesticated cattle. Immunol. Rev., 167: 145-158.

Lindhe, B. and J. Philipsson, 1998. Genetic corelations between production with disease resistance and fertility in dairy cattle and consequences for total merit selection. Acta Agic. Scand., Sect. A, 48: 216-221.

Lunden, A., S. Sigurdradottir, I. Edfors-Lilja, B. Darrell, J. Rendel and L. Andersson, 1990. The relationship between bovine major histocompatibility complex class II polymorphism and disease studied by the use of bull breeding values. Anim. Genet, 21: 221-232.

Machado, M.A., C.S. Nascimento and M.L. Martinez, 2005. Association of BoLA-DRB3.2 locus with bovine milk production in Gir breed. Arq. Bras. Med. Vet. Zootec., 57: 380-389.

Maillard, J.C., D. Berthier, I. Chantal, S. Thevenon and I. Sidibe et al., 2003. Selection assisted by a BoLA-DR/DQ haplotype against susceptibility to bovine dermatophilosis. Gen. Sel. Evol., 35: 193-200.

Mallard, B.A., K.E. Leslie, J.C. Dekkers, R. Hedge, M. Bauman and M.J. Stear, 1995. Differences in bovine lymphocyte antigen associations between immune responsiveness and risk of disease following intramammary infection with Staphylococcus aureus. J. Dairy Sci., 78: 1937-1944.

Mejdell, C.M., O. Lie, H. Solbu, E.F. Arnet and R.L. Spooner, 1994. Associations of major histocompatibility complex antigens (BoLA) with bull progeny test results for mastitis, ketosis, and fertility in Norwegian cattle. Anim. Gen., 25: 99-104.

Miretti, M.M., J.A. Ferro, M.A. Lara and E.P.B. Contel, 2001. Restriction fragment length polymorphism (RFLP) in Exon 2 of the BoLA-DRB3 gene in South American cattle. Biochem. Genet., 39: 311-324.

Oddgeirsson, O., S.P. Simpson, A.L.G. Morgan, D.S. Ross and R.L. Spooner, 1988. Relationship between the bovine major histocompatibility complex (BoLA), erythrocyte markers and susceptibility to mastitis in Iceland cattle. Anim. Genet., 19: 11-16.

Oltenacu, P.A. and I. Ekesbo, 1994. Epidemiological study of clinical mastitis in dairy cattle. Vet. Res., 25: 208-212.
Schukken, Y.H., B.A. Mallard, J.C.M. Dekkers, K.E. Leslie and M.J. Stear, 1994. Genetic impact on the risk of intramammary infection following Staphylococcus aureus challenge. J. Dairy Sci., 77: 639-647.

Sharif, S., B.A. Mallard, B.N. Wilkie, J.M. Sargeant, H.M. Scott, J.C.M. Dekkers and K.E. Leslie, 1998. Associations of the bovine major histocompatibility complex DRB3 (BoLA-DRB3) alleles with occurrence of disease and milk somatic cell score in Canadian dairy cattle. Anim. Genet., 29: 185-193.

Sharif, S., B.A. Mallard, B.N. Wilkie, J.M. Sargeant, H.M. Scott, J.C.M. Dekkers and K.E. Leslie, 1999. Associations of the bovine major histocompatibility complex DRB3 (BoLA-DRB3) with pro-duction traits in Canadian dairy cattle. Anim. Genet., 30: 157-160.

Sharif, S., B.A. Mallard and J.M. Sargeant, 2000. Presence of glutamine at position 74 of pocket 4 in the BoLADR antigen binding groove is associated with occurrence of clinical mastitis caused by Staphylococcus species. Vet. Immunol. Immunopathol., 76: 231-238.

Smith, K.L. and J.S. Hogan, 1993. Environmental mastitis. Vet. Clinics of North America: Food Anim. Pract., 9: 489-498.

Starkenburg, G.E., I.G. Udina, G.O. Shaikhaev and H. Chester-Jones, 1997. Frequencies and effects of alternative $D R B 3.2$ alleles of bovine lymphocyte antigen for Holstein in milk selection and control lines. J. Dairy Sci., 80: 3411-3411.

Takeshima, S., M. Ikegami, M. Morita, Y. Nakai and Y. Aida, 2001. Identification of new cattle BoLA-DRB3 alleles by sequence-based typing. J. Immunogenet., 53: 74-81.

Van Eijk, M.J.T., J.A. Stewart-Haynes and H.A. Lewin, 1992. Extensive polymorphism of the BoLA-DRB3 gene distinguished by PCR-RFLP. Anim. Genet., 23: 483-496.

Vukasinovic, N., M.L. Martinez, A.E. Freeman, A.B. Dietz and M.E. Kehrli Jr., 1997. Association of the bovine lymphocyte antigen $D R B 3$ locus with economically important traits in dairy cattle. J. Dairy Sci., 80: 3411-3419.

Waller, K.P., T. Westermark, T. Ekman and K. Svennersten-Sjaunja, 2003. Milk leakage: An increased risk in automatic milking systems. J. Dairy Sci., 86: 3488-3497.

Whitaker, D.A., J.M. Kelly and S. Smith, 2000. Disposal and disease rates in 340 British dairy herds. Vet. Rec., 146: 363-367.

Xu, A.L., M.J.T. Vaneijk, C. Park and H.A. Lewin, 1993. Polymorphism in BoLA-DRB3 exon 2 correlates with resistance to persistent lymphocytosis caused by bovine leukemia virus. J. Immunol., 151: 6977-6985. 